\title{
Forest site classification activities in Northern Canada
}

\author{
by E. T. Oswald ${ }^{1}$
}

\begin{abstract}
Historically, site classification north of $60^{\circ} \mathrm{N}$. Lat. includes related activities conducted by geologists over the last century, particularly the information presented on surficial materials. Ecological land classification provides a technique suitable for evaluating the capability of the land base to satisfy the requirements of various renewable resource sectors. Ecological Land Surveys that included an assessment of forest capability have been used over much of northern Canada. A forest inventory, or cover mapping, has been done for part of the forest environment. The demands on the forest resource are increasing, not only for the utilization of wood products, but also for recreational facilities, tourism, and wildlife habitat. Forest site classification based on ecological factors is essential to provide an informed basis for making resource management and utilization decisions. Some site classification techniques are discussed, and recommendations made in support of continuing classification and surveys for more intensive management and for the preservation and analyses of ecological reserves.
\end{abstract}

\section{Résumé}

Au nord du $60^{\mathrm{e}}$ parallèle, la classification des sites a toujours inclus des activités menées par les géologues au cours du siècle dernier, notamment les données sur les matériaux de surface. La classification écologique du territoire offre une technique permettant d'évaluer l'aptitude des terres à répondre aux exigences de divers secteurs des ressources renouvelables. Des relevés écologiques du territoire, qui comportaient une évaluation des possibilités forestières, ont été réalisés dans la majeure partie du nord du Canada. On a dressé un inventaire forestier ou une carte topographique de certaines parties du milieu forestier. Les demandes exercées sur les ressources forestières ne cessent d'augmenter, non seulement à l'égard des produits du bois, mais également à l'égard des installations récréatives, touristiques et des habitats fauniques. La classification des sites forestiers, fondée sur des facteurs écologiques, est un outil essentiel à l'obtention d'une base de données bien documentée, permettant de prendre des décisions en matière d'utilisation et de gestion des ressources. L'auteur examine certaines techniques de classification des sites et formule des recommandations en faveur d'une classification et de relevés permanents conduisant à une gestion plus intensive ainsi qu'à la conservation et à des analyses des réserves écologiques.

\section{Introduction}

Studies related to forest site classification in Canada north of $60^{\circ} \mathrm{N}$. Lat. have been sporadic at best, largely due to the low esteem in which these forests are held by most relevant managers. Historically northern Canada has been, and for the most part still is, sparsely populated. Consequently, there has been little need for intensive renewable resource management. Also, transportation costs impact negatively on marketing any resource product.

The primary resource concerns in northern Canada since about 1850 have been for mineral and fossil fuel exploration and extraction. Geological explorations and mineral extractions have combined traditional prospecting and stateof-the-art technology. Any management of wildlife habitat during this period was mostly by native peoples, while much wildlife exploitation was done by fur traders. Steamboats in the Yukon used the accessible wood along the Yukon River and major tributaries for fuel; subsequently most forestry practices have continued to be directed towards local consumption, largely by the mining industry and as cord wood. The economy of the north has been governed chiefly by revenues from mineral extraction. However, limitations to mining during the past decade have shifted interests to other resource sectors, and brought about a need for a closer look at site classification and what it may offer for land and resource allocation and utilization.

Although the earlier surveys were mostly for purposes other than land, site, or forestry classification, some pertinent information was made available. Geological surveys led

${ }^{1}$ Forestry Canada Pacific Forestry Centre, 506 W. Burnside Road Victoria, B.C. V8Z 1M5

to descriptions of bedrock and surficial geology for many areas. Access was mostly along rivers during the summer, and dog teams during the winter (though a few geologists used horses) so that the surveys were done mostly in valleys. The construction of the Alaska Highway in 1942 provided access to the forested part of southern Yukon, and allowed investigations by botanists, ecologists, and agriculturalists of the vegetation, soils, climate, and forest cover. The roads to Yellowknife and Norman Wells in the Northwest Territories (N.W.T.) did not attract as many "naturalists" as the Alaska Highway, or other subsequent roads in the Yukon. Consequently early information on site classification from the N.W.T. is virtually non-existent. Aerial photography became available in the late 1940s and early 1950s, mostly through military testing missions. Very little documented use was made of this photography for land classification until more recent times.

This report is concerned with some of the preliminary work related to land and site classification. It reviews recent surveys, summarizes the current state of knowledge and offers some recommendations, mostly from a forestry perspective.

\section{Land Resource Surveys}

Early surveys related to terrain classification were conducted in relation to mineral exploration (Bostock 1973). Camsell (1936) was among the first to use air photographs, these being mostly oblique photos taken along a single flight line across southeastern Yukon and into the N.W.T. From these photos, he described the physiography and general vegetation. Bostock (1948) described and mapped the physiography of the Yukon. Hughes et al. (1969) described the 
glacial flow patterns. Raup (1934) explored and described the vegetation in relation to physiography from ground surveys, but later Raup and Denny (1950) used aerial photographs to describe the terrain and vegetation along the Alaska Highway. Jeffrey (1964) conducted a similar survey of southwest N.W.T.

On the basis of these early surveys of physiography and vegetation, later resource-related work was directed to areas of specific interest. With the use of information obtained from prospectors and ground surveys, the geology was described and mapped (see references in Hughes et al. 1972 and Pettapiece et al. 1978). Vernon and Hughes (1966) mapped the surficial geology of west-central Yukon. Day (1962) conducted a reconnaissance soil survey of part of south-central Yukon for the purpose of developing agricultural pursuits. The arctic climate was described by Weller and Bowling (1973), and climatic data for specific areas were often included in various resource classification, description, and mapping reports. Brown (1978) mapped the permafrost distribution.

Halliday (1937) and Rowe (1972) included northern Canada in their work on forest regions. Gairns (1968) mapped the forest resource of the Yukon, and Peaker (1968) and Hirvonen (1968) described the forest conditions in areas with the most promise for productive tree growth. Forest cover surveys were performed with large-scale photo sampling in the Yukon (Nielsen et al. 1979; Rymer 1986), and with conventional aerial photography of the Lower Liard District, N.W.T. (Department of Indian and Northern Affairs 1986). A reconnaissance inventory of forest volume and biomass for southern Yukon was conducted by Bonnor and Oswald (1988).

\section{Site Classification}

The first comprehensive approach to resource classification relevant to site classification was put forth by the Subcommittee on Biophysical Land Classification (Lacate 1969), and integrated base data inventories were addressed in a technical workshop (Romaine and Ironside 1979). The Arctic Land Use Research Program employed some of these guidelines in studies around Watson Lake, Yukon and in southwestern N.W.T. (Lavkulich 1973; Murray et al. 1973; Lavkulich and Walmsley 1974); the concepts were also utilized in some of the surveys conducted in preparation for the Mackenzie Valley gas pipeline (Crampton 1973; Zoltai and Pettapiece 1973; Hettinger et al. 1973; Reid 1974; Reid and Janz 1974). The anticipated need for hydro-electric power led to surveys of some watersheds (Robertson and Eliasen 1974), while continued interest in resource development led to studies in the Watson Lake area (Reid 1975).
The need for a renewable resource data base by the Canadian Forestry Service gave rise to the delineation and description of "ecoregions" (Oswald and Senyk 1977). The concepts of ecoregions differed somewhat from the regions advocated by Lacate (1969) in that the regions were units of the landscape influenced by a particular climate as reflected by the vegetation, while ecoregions were units of the landscape possessing a uniform physiography and supporting a particular vegetation pattern based on species composition under the influence of a particular climate. In essence, the physiography, vegetation, and climate are given equal weight for describing units in the ecoregion concepts. Other land classification systems are available (Corns and Annas 1986; Environmental Conservation Service Task Force, undated; Pojar 1983) which are correlated in Table 1. The classification information can be put into a computerized geographic information system (GIS) (Lee et al. 1978).

The probability of a pipeline or other petroleum-related development in northern Yukon, and the possible effects this would have on wildlife and related resources in an area proposed for an international park, sparked Parks Canada to support an ecological survey for most of the area north of the Ogilivie Mountains (Wiken et al. 1981). This survey employed concepts similar to the ecoregions and advanced the development of the Ecological Land Survey (ELS) system through the ecodistrict level. A similar study was conducted in the N.W.T. (Bradley et al. 1982).

The Lands Directorate embarked on a plan to describe and map the ecodistricts for all of Canada and put the data into a GIS (Senyk et al. 1988). Some studies followed the concepts of the ELS system in classifying areas for recreational development to the ecosection level (Senyk et al. 1981), but in some cases the resource components were not amalgamated into ELS units (Davies et al. $1983 \mathrm{a}, \mathrm{b}$ ). The resource data for Kluane National Park Reserve obtained over several years by specialists in various fields was recently put together (Gray 1987), but additional correlation is necessary to present the information on a site-specific basis. A study was conducted within part of one ecoregion in the Yukon to classify the forested terrain (Oswald 1979) at the Ecosite level. The environmental assessment of the proposed Alaska Highway pipeline resulted in resource data being collected, some of which were pertinent to site classification (Orloci and Stanek 1979; Redpath 1979; Stanek 1980, 1982; Stanek and Orloci 1987).

Other recent work related to site classification includes a description of the forest communities in one ecoregion (Oswald and Brown 1986). As indicated by these later surveys, the vegetation requires a classification separate from the terrain, but correlated with it. Table 2 portrays a number

Table 1. Land classification systems performed by various agencies

\begin{tabular}{lll}
\hline ELS $^{1}$ & \multicolumn{1}{c}{ Alberta $^{\mathbf{1}}$} & British Columbia $^{\mathbf{1}}$ \\
\hline Ecoprovince & Biogeoclimatic Reg. & Information $^{\mathbf{2}}$ \\
Ecoregion & Ecoregion & Biogeoclimatic Zone \\
Ecodistrict & Ecosubregion & Biogeoclimatic Subzone \\
Ecosection & Ecosystem Assoc. & Climatic Region \\
Ecosite & Ecosystem Type & Ecosystem Assoc. \\
Ecoelement & Biogeocoenose & Biogeocoenose \\
\hline
\end{tabular}

'Ecological Land Survey of the Canada Committee on Ecological Land Survey (Environmental Conservation Service Task Force); Alberta system is according to Corns and Annas (1986); British Columbia system is after Pojar (1983).

${ }^{2}$ Indicates the quantity of information about the site required to classify at each level. 
Table 2. Vegetation classification systems utilized by various agencies.

\begin{tabular}{|c|c|c|c|c|c|}
\hline California $^{1}$ & $\begin{array}{l}\text { U.S. For } \\
\text { Service }^{2}\end{array}$ & $\begin{array}{c}\text { Jones et al. \& } \\
\text { Stanek }^{1}\end{array}$ & Alberta $^{1}$ & $\begin{array}{c}\text { British } \\
\text { Columbia }^{1}\end{array}$ & Damman $^{1}$ \\
\hline \multicolumn{6}{|l|}{ Formation } \\
\hline \multicolumn{6}{|l|}{ Subformation } \\
\hline Series & Series & $\begin{array}{l}\text { Operational } \\
\text { group }\end{array}$ & $\begin{array}{l}\text { Ecosystem } \\
\text { type }\end{array}$ & & $\begin{array}{l}\text { Forest } \\
\text { types }\end{array}$ \\
\hline Association & $\begin{array}{l}\text { Habitat } \\
\text { type }\end{array}$ & $\begin{array}{l}\text { Vegetation } \\
\text { type }\end{array}$ & Facies & $\begin{array}{l}\text { Ecosystem } \\
\text { Association }\end{array}$ & $\begin{array}{l}\text { Forest } \\
\text { type }\end{array}$ \\
\hline Phase & & & & & \\
\hline
\end{tabular}

${ }^{1}$ The California system is after Paysen et al. (1980).

The U.S. Forest Service system is according to Steele et al. (1983).

Jones et al. (1983) and Stanek (1980) have a similar system.

The Alberta system is according to Corns and Annas (1986).

The B.C. system is after Pojar (1983).

Damman's system for Newfoundland is by Meades and Moores (1989).

${ }^{2}$ Alexander (1988) uses Community Types for seral stages.

of vegetation classification systems: some are only for vegetation, while others are parts of terrain systems. A Canadian vegetation classification system (Strong et al. 1990) has been developed for use with ELS, but does not follow equivalent hierarchy to that indicated in Table 2.

\section{Operational Groups}

Stanek and Orloci (1987) defined eight silvicultural ecosystems, termed "operational groups," through an amalgamation of previously defined vegetation types (Orloci and Stanek 1979; Stanek 1980) using the concepts of Jones et al. (1983). The operational groups outlined for the Yukon pertain only to forested ecosystems which require the presence of a mature tree stratum for identification. Statistical evaluation (mostly cluster analysis or ordination) of vegetation and environmental factors disclosed the operational group indicators. The sequence for identifying an operational group as defined by Stanek and Orloci (1987) is: (1) select the appropriate tree category, (2) confirm with an understory species, (3) estimate the merchantability of the trees and (4) note the presence of permafrost within one meter of the soil surface. If spruce is predominant in the tree category, then site index is used to determine the final operational group.

The concepts of operational groups have merit, and the descriptions as presented offer some silviculturally useful ecological information about the site such as ecoregion, forest cover, site index, vegetation type, soil characteristics, and moisture regime. Once the operational group is determined, it is then possible to make interpretations covering the planning, harvesting, and regeneration of the stand. Some interpretations are presented in the operational group descriptions, and include such things as harvesting and reforestation options, most desired species per site, and stand tending possibilities.

More work is required to include all vegetation types in the operational groups and to bring ecologically equivalent vegetation types together. In the key presented by Stanek and Orloci (1987), spruce (white and black) and tamarack are included in the same initial group, yet the ecological amplitude of these species is quite different, and white spruce is the only species forming merchantable operational groups. However, merchantability is not a good criterion for partitioning a biological system. Other complications in using

the procedure come with the indicated subordinate vegetation which is not exclusive to the tree group it is listed in, the absence of indicator species in some stands, and in the abundance of mixed and seral stands present in northern Canada. The stratification, however, can be useful to the field forester in many situations.

\section{Forest Communities}

The plant communities supporting tree cover in an ecoregion consisting mostly of a large valley with elevations ranging from $600 \mathrm{~m}$ to $2000 \mathrm{~m}$ above sea level were described by Oswald and Brown (1986). The community descriptions include general statements on the vegetation, common elevation for the community, characteristic and associated species, landform and soils, successional status, and productivity which includes basal area, volume, mean annual increment, and age data. The communities are similar to the vegetation types and phases of Stanek (1980), but do not incorporate the hierarchy of the vegetation types.

The forest communities include both seral and stable plant assemblages; thus the term "plant community" is used rather than "plant association" which is reserved for stable or "climax" species groups. They are primarily aimed for utilization with existing vegetation, but the stable association can be inferred once the successional (seral) sequences are elucidated and analyzed in relation to the substrate parameters (mostly soil texture, moisture regime, aspect, and elevation). The productivity class can be determined or estimated even if the trees are not present by examination of the physical site features and the subordinate vegetation (Oswald and Brown 1990). Interpretations can be made for various silvicultural practices.

Several communities were recognized, and other seral phases exist that may have one or two species at variance with those in a described community but have the same ecological equivalence. For making interpretations, it is useful to group the communities, on the basis of site and vegetation characteristics, into ecologically equivalent categories similar to the operational groups. For example, an abundance of Arctostaphylos uva-ursi indicates a dry, most often sandy, site of medium productivity which can support an overstory of Picea glauca, Pinus contorta, or Populus tremuloides within the ecoregion studied. Since the site characteristics are very similar, the silvicultural practices and interpretations 
for managing these sites would also be very similar. However, because the tree species change, the operational groups as defined would not reveal the true similarity among these sites, so that a different definition must be devised. Perhaps a stratification for operational groups based on understory species would have more ecological significance than using the tree strata.

\section{Discussion}

The mobility of the human population brought about by technological advances (and improved access) is placing increasing demands on the forests, and other land resources, in what used to be the remote northern areas. These increased demands necessitate some holistic view of the resource field to even attempt to satisfy the various users. In consideration that there are $20,490,000$ ha $(9 \%$ of the total amount in Canada) of land area for timber production north of $60^{\circ} \mathrm{N}$. Lat., containing wood volume of $700,000,000 \mathrm{~m}^{3}$ (Honer and Bickerstaff 1985), it is justifiable to support a site classification program in this area to assist resource management. Much of the area has been covered by the Ecological Land Classification procedures at the ecoregion and ecodistrict levels, but very little by an intensive forest site classification.

Land in the north has relatively low forest productivity when compared to southern British Columbia, or much of the southern boreal forest, yet it has high values for the socioeconomy of the north. The value lies in recreation, tourism, aesthetics, and wildlife habitat as well as wood production. Therefore, ecological factors other than those necessary for just growing merchantable trees must be included in any assessment of site analysis and classification.

The primary factors influencing tree productivity are climate, physiography, and soils, but these are interrelated and thus difficult to separate for assessment. The most important elements of climate are cold temperatures, short growing season, and limited precipitation, which are only partially compensated for by the long day length during the growing season. Daily temperatures can fluctuate over a wide range during a $24-\mathrm{h}$ period; a $24-\mathrm{h}$ range of $30^{\circ} \mathrm{C}$ or more may occur in the spring or fall.

Physiography plays a controlling role on the climate. The elevation differences brought about by the mountain ranges, allow for vast climatic differences. In general, tree growth is restricted to the lower slopes and valleys, but there are species differentiations from valley floor to tree line and between the northerly and southerly aspects. Cold air pooling and drainage arising from temperature inversions may restrict tree growth in some valleys. Precipitation at upper elevations, particularly the windward aspects, tends to be more plentiful than at lower elevations, and higher ranges get more than lower ranges.

The primary features of soils include texture and organic matter content, but alkalinity is a prominent factor in some places. Coarse-textured soils tend to be warmer but drier; soils with high organic matter content are often colder and wetter, but have a higher nutrient content-provided they are not supersaturated or frozen. The optimal balance is for moderately coarse-textured soils with a shallow but moving water table, such as some alluvial sites at lower elevations that lack permafrost. Such sites are few and have the greatest use allocation conflicts.
The most important attributes of a forest site classification system include provision for assessing forest productivity, and for extrapolating the site data from one site to another. Obviously, the amount of site energy put into tree growth is reduced by the amount put into the associated vegetation, lost to the atmosphere, or dissipated through some other means, and these must be accounted for in biomass assessments. Although classification is a site-specific event, in order for it to be useful, the information gained from analyses of one site must be extrapolatable to another site; this forms the basis of mapping. An important aspect of extrapolating information from one site to another is the amount of variability (range) permissible or allowed in the various site parameters. There are commonly fairly continuous gradients on mountain slopes of increasing soil depth, amount of moisture and nutrients received from up slope, and tree heights with decreasing elevation. The decision on amount of allowable variation in site parameters must be made before lines can be drawn separating these slopes into site types.

The data obtained by sampling a site provides only the basis for making interpretations. The data itself has little real significance unless it is compared to the data obtained from another site or to some presumed "normal", or standard. It is through this means that sites can be evaluated in terms of their potential for forestry, agriculture, recreation, wildlife habitat, trafficability, etc. In general, these land uses are evaluated for the site in its natural, unmodified state. From this, the best unmanaged use of the site can be determined. However, interpretations can go beyond this and indicate sites that would yield economic returns in agriculture or forestry from fertilization, thinning, and other stand tending. Some non-renewable resource interpretations, such as location and quantities of materials for road construction, trafficability, and erosion hazard, can be made. To make these interpretations, information from analyses by multidisciplinary resource teams and verification by historical trials and documented uses is required. Allowance must be made for changes in the socio-economics of the area.

\section{Recommendations}

- The entire area north of $60^{\circ} \mathrm{N}$. Lat. should be covered with a broad scale classification and mapping at the Ecoregion and Ecodistrict levels. Much of this is already done (Senyk et al. 1988), but areas not covered need to be completed; contiguous maps should be assembled.

- Resource priorization must be done on the basis of the above surveys and maps. This could take the form of the Canada Land Inventory procedures, modified to meet the needs of northern Canada.

- Each resource group should concentrate initially on lands with the highest priority for the particular resource. More detailed classification and mapping should be performed within the broad scale framework.

- It would be useful to generate a GIS data base for maintaining up-to-date files as social and economic trends change, and to assist data access for making management decisions. 


\section{Forestry Group Concerns}

- All forest lands, beginning with the most productive lands, should be classified at the Ecosite level. Analysis of the site potential as well as standing crop must be conducted. This will involve forest cover as well as vegetation classification and site descriptions.

- Vegetation successional patterns must be elucidated for each site type, and ecological equivalence determined even where the tree species or cover differ.

- Seral vegetation types should be grouped into ecologically equivalent groups through the use of physical site information.

- All necessary interpretations must be made on the basis of the physical and biological site data in concert with social needs. Factors to consider include tree species allocation, productivity assessments, trafficability, erosion hazard, silvicultural requirements, and conflicts with other resources.

- Harvesting schedules and procedures must be devised to be appropriate for the maintenance of economic tree removal, aesthetic appeal, sustainable growth, and avoidance of site degradation.

- Management strategies should be developed to encompass the physical and biological features of each site type, preserve or enhance the productivity, and promote economical utilization of the forest resource.

- Ecological reserves that encompass a wide variety of ecological conditions must be established. These must be large enough to ensure the integrity of the sites and biological systems; they must be preserved in perpetuity; they must be surveyed in detail, and their diversifications should be monitored over several centuries.

\section{References}

Alexander, R.R. 1988. Forest vegetation on national forests in the Rocky Mountain and Intermountain Regions: Habitat types and community types. U.S.D.A., For. Ser. Gen. Tech. Rep. RM-162. 47 p.8

Bonnor, G.M. and E.T. Oswald. 1989. The Yukon forest reconnaissance inventory 1985. For. Can., Pac. For. Cent., BC$\mathrm{X}-315.30 \mathrm{p}$.

Bostock, H.S. 1948. Physiography of the Canadian Cordillera, with special reference to the area north of the fifty-fifth parallel. Geol. Sur. Can. Mem. 247. 106 p.

Bostock, H.S. (Comp.) 1973. Yukon Territory: Selected field reports of the geological survey of Canada 1898 to 1933. Dept. Energy, Mines and Res., Geol. Sur. Can. Mem. 284. $650 \mathrm{p}$.

Bradley, S.W., J.S. Rowe and C. Tarnocai. 1982. An ecological land survey of the Lockhart River map area, Northwest Territories. Environ. Can., Lands Dir., Ecol. Land Class. Ser., No. 16. 152 p.

Brown, R.J.E. 1978. Permafrost. Hydrological Atlas of Canada, Fish. Environ. Can., Ottawa, Ont. Plate 32.

Camsell, C. 1936. Flying through northwestern Canada. Can. Geogr. J. 12: 112-122.

Corns, I.G.W. and R.M. Annas. 1986. Field guide to forest ecosystems of west-central Alberta. For. Can., North. For. Cent. 251 p.

Crampton, C.B. 1973. Landscape survey of the upper and central Mackenzie Valley. Environmental-Social Committee Northern Pipelines. Rep. No. 73-8. 67 p.
Davies, D., C.E. Kennedy, and K. McKenna. 1983a. Resource inventory - Southern Lakes. Land Plan. Br., Dept. Renew. Resour., Gov. Yukon. 151 p. Appendices.

Davies, D., C.E. Kennedy and K. McKenna. 1983b. Coal River Springs preliminary biophysical inventory. Land Plan. Br., Dept. Renew. Resour., Gov. Yukon. 78 p.

Day, J.H. 1962. Reconnaissance soil survey of the Takhini and Dezadeash valleys in the Yukon Territory. Can. Dept. Agric. $78 \mathrm{p}$.

Department of Indian and Northern Affairs. 1986. Coniferous and deciduous volume estimates with proposed requirements for the harvest of white spruce sawtimber in the Lower Liard Timber District, N.W.T. Lower Liard River Timber Inventory, 1982, revised 1986, Book One, 73 p. plus Appendices, Book Two, All Appendices, Book Three, Cover Type Maps, Book Four, Environmental Maps. D.I.N.A., Ft. Smith, N.W.T.

Environmental Conservation Service Task Force. (Undated). Ecological land survey guidelines for environmental impact analysis. Lands Dir. - FEARO, Ecol. Land Class. Ser., No. 13. 42 p.

Gairns, C.H. 1968. The Yukon economy: Its potential for growth and continuity. Forest resources study. Vol. III. Reference Study on Forest Resources. Rep. for Dept. of Indian Affairs and Northern Devel., D.W. Carr Assoc., 62 p.

Gray, B.J. 1987. Resource description and analysis. Kluane National Park Reserve. Two Vols. Environ. Can., Parks.

Halliday, W.E.D. 1937. A forest classification for Canada. Can. Dept. Mines and Resour., For. Serv. Bull. 89. King's Printer, Ottawa, Ont.

Hettinger, L., A. Janz and R.W. Wein. 1973. Vegetation of the northern Yukon Territory. Arctic Gas, Biological Rep. Ser., Vol. One, Northern Engineering Services Co. Ltd. 171 p.

Hirvonen, R.P. 1968. Report on forest conditions in the Nisutlin River area, Yukon Territory. Dept. For. Rural Devel., For. Manag. Inst., Northern Surveys Rep. No. 5. 11 p.

Honer, T.G. and A. Bickerstaff. 1985. Canada's forest area and wood volume balance 1977-1981. Can. For. Serv., Pac. For. Cent., BC-X-272. 84 p.

Hughes. O.L., R.B. Campbell, J.E. Muller and J.O. Wheeler. 1969. Glacial limits and flow patterns, Yukon Territory, south of 65 degrees north latitude. Dept. Ener, Mines Resour., Geol. Sur. Can., Paper 68-34, 9 p. Map.

Hughes, O.L., V.N. Rampton and N.W. Rutter. 1972. Quaternary geology and geomorphology, southern and central Yukon. XXIV International Geological Congress, Guidebook for Field Excursion A11. 59 p.

Jeffrey, W.W. 1964. Forest types along the Lower Liard River, Northwest Territories. For. Res. Br., Dept. For., Publ. No. 1035. $103 \mathrm{p}$.

Jones, R.K., G. Pierpoint, G.M. Wickware, J.K. Jeglum, R.W. Arnup and J.M. Bowles. 1983. Field guide to forest ecosystem classification for the clay belt, site region $3 \mathrm{e}$. Min. Nat. Resour., Queens Printer Ont. 123 p.

Lacate, D.S. (Editor). 1969. Guidelines for biophysical land classification. Dept. Fish. For., Can. For. Serv., Pub. No. 1264. $61 \mathrm{p}$.

Lavkulich, L.M. 1973. Physical environmental studies, Watson Lake, Yukon Territory. Ind. North. Affairs, ALUR 1972-73-01. 278 p.

Lavkulich, L.M. and M.E. Walmsley. 1974. Physical environment studies: Characterization of soil hydrologic parameters, Watson Lake, Yukon Territory. Ind. North. Affairs, ALUR 1973-74-01. 42 p.

Lee, Y.J., D. Hunt and T.G. Honer. 1978. Yukon RRAMS, An information retrieval system for renewable resource and management statistics. Environ. Can., Can. For. Serv., BC$\mathrm{X}-185.16 \mathrm{p}$. 
Meades, W.J. and L. Moores. 1989. Forest site classification manual: A field guide to the Damman forest types of Newfoundland. FRDA Rep. 003. 119 p.

Murray, J.M., J.S. Rowe, F.G. Olfert and D.M. Gubbe. 1973. Hydrologic and ecologic studies related to land use near Watson Lake, Yukon Territory. Ind. North. Affairs, ALUR 1973-74-73. $72 \mathrm{p}$

Nielsen, U., A.H. Aldred and D.A. MacLeod. 1979. A forest inventory in the Yukon using large scale photo sampling techniques. Can. For. Ser., For. Manage. Inst., FMR-X-121. 40 p.

Orloci, L, and W. Stanek. 1979. Vegetation survey of the Alaska Highway, Yukon Territory: types and gradients. Vegetatio 41.1: $1-56$.

Oswald, E.T. (comp.) 1979. Forest resource assessment of the Nisutlin test area. A file report by Pacific Forest Research Centre, For. Manage. Inst., and Yukon Lands and For. Serv. $79 \mathrm{p}$.

Oswald, E.T. and B.N. Brown. 1986. Forest communities in Lake Laberge Ecoregion, Yukon Territory. Can. For. Serv., Pac. For. Cent., BC-X-282. 97 p.

Oswald, E.T. and B.N. Brown. 1990. Vegetation establishment during 5 years following wildfire in northern British Columbia and southern Yukon Territory. For. Can., Pac. For. Cent., BC-X-320. 46 p.

Oswald, E.T. and J.P. Senyk. 1977. Ecoregions of Yukon Territory. Environ. Can., Can. For. Serv., Pac. For. Cent., BC$\mathrm{X}-164.115 \mathrm{p}$.

Paysen, T.E., J.A. Derby, H. Black, Jr., V.C. Bleich and J.W. Mincks. 1980. A vegetation classification system applied to southern California. U.S.D.A., For. Serv., Gen. Tech. Rep. PSW-45. $33 \mathrm{p}$

Peaker, J.P. 1968. Report on the forest conditions in the Upper Liard River Area, Yukon Territory. Dept. For. Rural Devel., For. Manage. Inst., North. Sur. Rep. No. 6. 9 p.

Pettapiece, W.W., C. Tarnocai, S.C. Zoltai and E.T. Oswald. 1978. Guidebook for a tour of soil, permafrost and vegetation relationships in the Yukon and Northwest Territories of Northwestern Canada. 11th Congress International Society of Soil Science, Tour 18. 165 p.

Pojar, J.(Editor). 1983. Forest Ecology. Pages 221-318 in: Forestry Handbook for British Columbia. Fourth Ed. Edited by S.B. Watts. Fac. of For., U.B.C. 611 p.

Raup, H.M. 1934. Phytogeographical studies of the Peace and Upper Liard River regions, Canada. The Arnold Arboretum of Harvard Univ., Contr. 6.

Raup, H.M. and C.S. Denny. 1950. Photo interpretation of the terrain along the southern part of the Alaska Highway. Geol. Surv. Bull. 963-D. U.S. Gov. Print. Off., Washington. Pp. 95-135.

Redpath, D.K. 1979. Land use programs in Canada. Yukon Territory. Environ. Can., Lands Direct. 303 p.

Reid, D.E. 1974. Vegetation of the Mackenzie Valley - Part one. Arctic Gas, Biological Rep. Series, Vol. Three, Northern Engineering Serv. Co. Ltd. 145 p.

Reid, D.E. 1975. Landscape classification in the Watson Lake Area, Yukon Territory. Master's thesis, Dept. of Plant Ecol., Univ. of Saskatchewan, Saskatoon. 187 p.
Reid, D.E. and A. Janz. 1974. Vegetation of the Mackenzie Valley - Part Two. Arctic Gas, Biological Rep. Series, Vol. Three, Northern Engineering Serv. Co. Ltd. 166 p.

Robertson, R.A. and B.R. Eliasen. 1974. Environmental engineering studies associated with the Aishihik River hydroelectric development. Environ. Can., Fish and Marine Serv. PAC/T-74-18.

Romaine, M.J. and G.R. Ironside. (Comp.) 1979. Canada's northlands. Proceedings of a technical workshop to develop an integrated approach to base data inventories for Canada's . northlands. Ecol. Land Class. Ser., No. 0. 124 p.

Rowe, J.S. 1972. Forest regions of Canada. Dept. Environ., Can. For. Serv., Publ. No. 1300. 172 p.

Rymer, K. 1986. Yukon report, Canadian Forest Inventory Committee. Yukon Lands For. Serv., File Rep.' Pp. 56-60.

Senyk, J.P., E.B. Wiken, G.R. Ironside and T.W. Pierce. 1988. Land capability of forestry: 1:1 000000 Map Series Yukon. Environ. Can., Inland Waters/Lands. Map.

Senyk, J.P., E.T. Oswald, B.N. Brown and R.K. King. 1981. Ecological land classification and evaluation of the Kusawa Lake area, Yukon Territory. Can. For. Serv., Pac. For. Cen., File Rep., 178 p.

Stanek, W. 1980. Vegetation types and environmental factors associated with Foothills Gas Pipeline Route, Yukon Territory. Environ. Can., Can. For. Serv., Pac. For. Cent., BCX-205. 48 p.

Stanek, W. 1982. Reconnaissance of vegetation and soils along the Dempster Highway, Yukon Territory: II. Soil properties as related to revegetation. Environ. Can., Can. For. Serv., Pac. For. Res. Cent., BC-X-236, 28 p.

Stanek, W. and L. Orloci. 1987. Some silvicultural ecosystems in the Yukon. Can. For. Serv., Pac. For. Cent., BC-X-293. $56 \mathrm{p}$.

Steele, R., S.V. Cooper, D.M. Ondov, D.W. Roberts and R.D. Pfister. 1983. Forest habitat types of eastern Idaho-western Wyoming. U.S.D.A., For. Ser., Gen. Tech, Rep. INT-144. $122 \mathrm{p}$.

Strong, W.L., E.T. Oswald and D.J. Downing. 1990. The Canadian vegetation classification system. C.C.E.L.C., Ecol. Land Class. Ser., No. 25. 22 p.

Vernon, P. and O.L. Hughes. 1966. Surficial geology, Dawson, Larsen Creek, and Nash Creek map areas, Yukon Territory. Dept. Energy, Mines Resour., Geol. Sur. Can., Bull. 136. $25 \mathrm{p}$.

Weller, G. and S.A. Bowling. (Editors). 1973. Climate of the Arctic. Geophys. Inst., Twenty-fourth Alaska Sci. Conf., Univ. Alaska, Fairbanks. 436 p.

Wiken, E.B., D.M. Welch, G.R. Ironside and D.G. Taylor. 1981. The northern Yukon: An ecological land survey. Environ. Can., Lands Dir. Ecol. Land Class. Ser., No. 6. $197 \mathrm{p}$.

Zoltai, S.C. and W.W. Pettapiece. 1973. Studies of vegetation, landform and permafrost in the Mackenzie Valley: Terrain, vegetation and permafrost relationships in the northern part of the Mackenzie Valley and northern Yukon. Environmental-Social Committee, Northern Pipelines, Task Force on Northern Oil Devel. Rep. No. 73-4. 105 p. 